\title{
Addressing Diversity in PTSD Treatment: Clinical Considerations and Guidance for the Treatment of PTSD in LGBTQ Populations
}

Nicholas A. Livingston, Ph.D. ${ }^{1,2,3, *}$

Danielle Berke, Ph.D. 4,5

James Scholl, Ph.D. ${ }^{2,3}$

Mollie Ruben, Ph.D. ${ }^{6}$

Jillian C. Shipherd, Ph.D. ${ }^{1,7,8}$

\footnotetext{
Address

*,1National Center for PTSD, Behavioral Science Division, Boston, MA, USA Email: nicholas.livingston@va.gov

${ }^{2}$ Department of Psychiatry, Boston University School of Medicine, Boston, MA, USA

${ }^{3}$ VA Boston Healthcare System, Boston, MA, USA

${ }^{4}$ Hunter College of the City University of New York, New York City, NY, USA

${ }^{5}$ The Graduate Center, City University of New York, New York City, NY, USA

${ }^{6}$ Department of Psychology, University of Maine, Orono, ME, USA

${ }^{7}$ National Center for PTSD, Women's Health Sciences Division, Boston, MA, USA

${ }^{8}$ Lesbian, Gay, Bisexual, and Transgender (LGBT) Health Program, Veterans Health

Administration, Washington, DC, USA
}

Published online: 16 March 2020

(C) Springer Nature Switzerland AG 2020

This article is part of the Topical Collection on PTSD

Keywords PTSD · Evidence-based treatment · Assessment · LGBT · Minority stress

\section{Abstract}

Purpose of review Trauma exposure is widespread but is especially common among lesbian, gay, bisexual, transgender, and queer (LGBTQ) individuals. LGBTQ individuals also experience higher rates of discrimination, victimization, and minority stress which can complicate posttraumatic stress disorder (PTSD) treatment but also represent independent intervention targets. In this review, we highlight existing evidence-based practices, current limitations, and provide recommendations for care in the absence of established guidelines for treatment PTSD among LGBTQ patients. 
Recent findings Trauma-focused therapies (e.g., CPT, PE) and medications (e.g., SSRIs, SNRIs) have shown benefit for people with PTSD. However, evaluations of these interventions have failed to examine the role of LGBTQ identities in recovery from trauma, and existing PTSD treatments do not account for ongoing threat to safety or the pervasive minority stress experienced by LGBTQ patients. In addition, many LGBTQ patients report negative experiences with healthcare, necessitating increased education and cultural awareness on the part of clinicians to provide patient-centered care and, potentially, corrective mental health treatment experiences.

Summary Providers should routinely assess trauma exposure, PTSD, and minority stress among LGBTQ patients. We provide assessment and screening recommendations, outline current evidence-based treatments, and suggest strategies for integrating existing treatments to treat PTSD among LGBTQ patients.

\section{Introduction}

Estimates suggest that $70-90 \%$ of the general population will experience a criterion A traumatic event at some point in their lives [1], which is defined as "exposure to actual or threatened death, serious injury or sexual violence" [[2]; p. 271]. Fortunately, most people who experience trauma do not develop posttraumatic stress disorder (PTSD), with the prevalence rate of PTSD in the general population between 6.8 and $8.3 \%[2,3]$. While no demographic group is immune to risk of trauma exposure, the nature, frequency, and severity of trauma exposure vary widely across groups. Epidemiological data suggests that individuals who identify as lesbian, gay, bisexual, transgender, or queer (LGBTQ) experience trauma, including violence and victimization, at higher rates than the general population [4-7]. Consequently, the estimated prevalence of PTSD tends to be higher among LGBTQ individuals, with rates ranging from 1.3 to $47.6 \%$ among LGB and 17.8 to $42 \%$ among transgender and gender diverse (TGD) individuals [8-14]. Thus, when treating LGBTQ patients, screening for trauma exposure and PTSD symptoms is essential (see Table 1).

Any effective assessment and/or intervention begin with high-quality patient-provider communication, which is the cornerstone of patient-centered care. With patient-centered care, the focus is on the specific needs and intentions of the patient and encouraging the exploration and expression of these goals during the visit while attending to patient concerns, feelings, and emotions [15]. For patients who identify as LGBTQ, this work can begin even before the patient and provider have met, through content and location of advertisements for services, waiting room signs inclusive of members of the LGBTQ community, and through use of inclusive paperwork (e.g., asking about preferred name, sexual orientation, and gender identity with all patients). Practical advice about how to approach creation of a welcoming environment is widely available $[16,17 \bullet \bullet$. Beyond this, it is incumbent on providers to practice with the fundamental background knowledge and cultural insight to enable effective patient-provider communication. However, few professionals have training in the unique needs of LGBTQ patients [18], which is essential for asking informed questions, establishing collaborative treatment plans, and engaging in the shared decision-making that makes patientcentered care possible [19].

In this review, we share some recommendations for working with LGBTQ patients, with considerable focus on understanding the unique experiential and cultural factors, as well as disparities, relevant to the care and recovery of LGBTQ patients. We also highlight several evidence-based interventions for PTSD, discuss current limitations, and suggest assessment (Tables 1 and 2) and intervention adaptations for providers to consider as they work with traumaexposed LGBTQ patients. 
Table 1. Existing evidence-based self-report assessment tools for trauma, PTSD, and related symptoms

\begin{tabular}{|c|c|c|c|}
\hline Measure & $\begin{array}{l}\text { No. of } \\
\text { Items }\end{array}$ & Assessment content & Reference \\
\hline $\begin{array}{l}\text { Life Events Checklist } \\
\text { for DSM-5 (LEC-5) }\end{array}$ & 16 & $\begin{array}{l}\text { Screener of lifetime } \\
\text { exposure to various } \\
\text { Criterion A traumas }\end{array}$ & $\begin{array}{l}\text { Weathers FW, Blake DD, Schnurr PP, } \\
\text { Kaloupek DG, Marx BP, Keane TM. The } \\
\text { Life Events Checklist for DSM-5 } \\
\text { (LEC-5). Retrieved from www.ptsd.va. } \\
\text { gov. Published 2013. Accessed } \\
\text { November 4, } 2019 \text {. }\end{array}$ \\
\hline $\begin{array}{l}\text { PTSD Symptom Checklist } \\
\text { for DSM-5 (PCL-5) }\end{array}$ & 20 & $\begin{array}{l}\text { Self-report of PTSD } \\
\text { symptoms severity in last } \\
30 \text { days; can be adapted } \\
\text { for varying lengths of time } \\
\text { (e.g., past week) }\end{array}$ & $\begin{array}{l}\text { Weathers FW, Litz BT, Keane TM, Palmieri } \\
\text { PA, Marx BP, Schnurr PP. The PTSD } \\
\text { Checklist for DSM-5 (PCL-5). } \\
\text { http://www.ptsd.va.gov. Published } \\
\text { 2013. Accessed November 4, } 2019 .\end{array}$ \\
\hline $\begin{array}{l}\text { PTSD Primary Care } \\
\text { Screen }\end{array}$ & 5 & $\begin{array}{l}\text { Developed to screen for } \\
\text { PTSD among veterans } \\
\text { in primary care settings; } \\
\text { can be use in other settings. }\end{array}$ & $\begin{array}{l}\text { Prins A, Bovin MJ, Smolenski DJ, Marx } \\
\text { BP, Kimerling R, Jenkins-Guarnierii } \\
\text { MA, et al. The Primary Care PTSD } \\
\text { Screen for DSM-5 (PC-PTSD-5): } \\
\text { Development evaluation within a } \\
\text { veteran primary care sample. J Gen } \\
\text { Intern Med 2019;31(10):1206-11. } \\
\text { Doi: https://doi.org/10. } \\
\text { 1007/s11606-016-3703-5. }\end{array}$ \\
\hline PHQ-9 & 9 & $\begin{array}{l}\text { Measure of depressed affect, } \\
\text { anhedonia, and suicide risk. } \\
\text { Note: Research has identified } \\
\text { an increased risk for suicidality } \\
\text { in LGBT population, special } \\
\text { attention should be given } \\
\text { to item } 9 \text {. }\end{array}$ & $\begin{array}{l}\text { Kroenke K, Spitzer RL. The PHQ-9: A new } \\
\text { depression diagnostic and severity } \\
\text { measure. Psychiatr Ann } \\
\text { 2002;32(9):509-15. Doi: https://doi. } \\
\text { org/10. } \\
\text { 3928/0048-5713-20,020,901-06. }\end{array}$ \\
\hline $\begin{array}{l}\text { The Impact of Events } \\
\text { Scale-Revised } \\
\text { (IES-R) }\end{array}$ & 15 & $\begin{array}{l}\text { Self-report scale examining } \\
\text { degree of distress associated } \\
\text { with a specific traumatic or } \\
\text { stressful event. }\end{array}$ & $\begin{array}{l}\text { Weiss D, Marmar C. The Impact of Event } \\
\text { Scale-Revised. In: Wilson JP, Keane } \\
\text { TM, edtiors. Assessing psychological } \\
\text { trauma and PTSD. New York: Guilford } \\
\text { Press; } 1997 .\end{array}$ \\
\hline $\begin{array}{l}\text { Depression, Anxiety } \\
\text { and Stress Scale } \\
\text { (DASS-21) }\end{array}$ & 21 & $\begin{array}{l}\text { Assessment of depression, } \\
\text { anxiety, and stress. }\end{array}$ & $\begin{array}{l}\text { Antony MM, Bieling PJ, Cox BJ, Enns MW, } \\
\text { Swinson RP. (1998). Psychometric } \\
\text { properties of the 42-item and 21-item } \\
\text { versions of the depression anxiety } \\
\text { stress scales in clinical groups and a } \\
\text { community sample. Psychol Assess } \\
\text { 1998;10(2):176-81. Doi: https://doi. } \\
\text { org/10.1037/1040-3590.10.2.176. }\end{array}$ \\
\hline $\begin{array}{l}\text { Center for Epidemiological } \\
\text { Studies Depression } \\
\text { Scale (CES-D) }\end{array}$ & 20 & $\begin{array}{l}\text { Assessment of depressive } \\
\text { symptoms in the past week. }\end{array}$ & $\begin{array}{l}\text { Lewinsohn PM, Seeley JR, Roberts RE, } \\
\text { Allen NB. } \\
\text { Center for Epidemiologic Studies } \\
\text { Depression Scale (CES-D) as a screening } \\
\text { instrument for depression among } \\
\text { community-residing older adults. Psychol }\end{array}$ \\
\hline
\end{tabular}


Table 1. (Continued)

\begin{tabular}{|c|c|c|c|}
\hline \multirow[t]{2}{*}{ Measure } & \multirow[t]{2}{*}{$\begin{array}{l}\text { No. of } \\
\text { Items }\end{array}$} & \multirow[t]{2}{*}{ Assessment content } & \multirow{2}{*}{$\begin{array}{l}\text { Reference } \\
\text { Aging 1997;12(2):277-87. Doi: } \\
\text { https://doi.org/10.1037//0882-7974.12. } \\
\text { 2.277. }\end{array}$} \\
\hline & & & \\
\hline $\begin{array}{l}\text { Generalized Anxiety } \\
\text { Disorder Screener } \\
\text { (GAD-7) }\end{array}$ & 7 & $\begin{array}{l}\text { Brief clinical measure for } \\
\text { assessing generalized } \\
\text { anxiety disorder symptoms. }\end{array}$ & $\begin{array}{l}\text { Löwe B, Decker 0, Müller S, Brähler, } \\
\text { Schellberg D, Herzog W. Validation } \\
\text { and standardization of the } \\
\text { Generalized Anxiety Disorder Screener } \\
\text { (GAD-7) in the general population. } \\
\text { Med Care 2008;46(3):266-74. Doi: } \\
\text { https://doi.org/10.1097/MLR. } \\
\text { Ob013e318160d093. }\end{array}$ \\
\hline $\begin{array}{l}\text { Alcohol Use Disorders } \\
\text { Identification Test } \\
\text { (AUDIT) }\end{array}$ & 10 & $\begin{array}{l}\text { Screening instrument for } \\
\text { hazardous and harmful } \\
\text { alcohol consumption }\end{array}$ & $\begin{array}{l}\text { Saunders JB, Aasland OG, Babor TF, de la } \\
\text { Fuente JR, Grant M. Development of } \\
\text { the Alcohol Use Disorders } \\
\text { IdentificationTest (AUDIT): WHO } \\
\text { collaborative project on early } \\
\text { detection of persons with harmful } \\
\text { alcohol consumption-II. Addiction } \\
\text { 1993;88:791-804. Doi: https://doi. } \\
\text { org/10.1111/j.1360-0443.1993. } \\
\text { tb02093.x. }\end{array}$ \\
\hline $\begin{array}{l}\text { Drug Use Disorders } \\
\text { Identification Test } \\
\text { (DUDIT) }\end{array}$ & 11 & $\begin{array}{l}\text { Brief screen of frequency and } \\
\text { negative consequences } \\
\text { associated with drug use }\end{array}$ & $\begin{array}{l}\text { Berman AH, Bergman H, Palmstierna T, } \\
\text { Schlyter F. Evaluation of the Drug Use } \\
\text { Disorders Identification Test (DUDIT) } \\
\text { in Criminal Justice and Detoxification } \\
\text { Settings and in a Swedish Population } \\
\text { Sample. European Addiction Res } \\
\text { 2005;11(1):22-31. Doi: https://doi. } \\
\text { org/10.1159/000081413. }\end{array}$ \\
\hline $\begin{array}{l}\text { Drug Abuse Screening } \\
\text { Test }\end{array}$ & $28 ; 10$ & $\begin{array}{l}\text { Brief assessment of drug } \\
\text { use and negative } \\
\text { consequences associated } \\
\text { with use }\end{array}$ & $\begin{array}{l}\text { Skinner HA. The Drug Abuse Screening } \\
\text { Test. Addict Behav 1982;7:363-71. } \\
\text { Doi: https://doi.org/10. } \\
\text { 1016/0306-4603(82)90005-3. }\end{array}$ \\
\hline $\begin{array}{l}\text { Suicidal Behaviors } \\
\text { Questionnaire-Revised } \\
\text { (SBQ-R) }\end{array}$ & 4 & $\begin{array}{l}\text { Brief self-report measure } \\
\text { of past suicidal behavior } \\
\text { and suicide risk }\end{array}$ & $\begin{array}{l}\text { Osman A, Bagge CL, Gutierrez PM, Konick } \\
\text { LC, Kopper BA, Barrios FX. The Suicidal } \\
\text { Behaviors Questionnaire-Revised } \\
\text { (SBQ-R): Validation with clinical and } \\
\text { nonclinical samples. Assessment } \\
\text { 2001;8(4):443-54. Doi: https://doi. } \\
\text { org/10.1177/107319110100800409. }\end{array}$ \\
\hline
\end{tabular}


Table 2. Existing evidence-based self-report assessment tools for discrimination, microaggressions, and minority stressors

\begin{tabular}{|c|c|c|c|}
\hline Measure & $\begin{array}{l}\text { No. of } \\
\text { Items }\end{array}$ & Assessment content & Reference \\
\hline $\begin{array}{l}\text { Everyday } \\
\text { Discrimination } \\
\text { Scale }\end{array}$ & 9 & $\begin{array}{l}\text { Screener of types and frequency } \\
\text { of everyday discrimination } \\
\text { (e.g., based on race/ethnicity, } \\
\text { age, sexual orientation). } \\
\text { Note: Can be adapted for daily use } \\
\text { to assess daily discrimination and } \\
\text { microaggressions [20] }\end{array}$ & $\begin{array}{l}\text { Williams DR, Yu Y, Jackson JS, Anderson } \\
\text { NB. Racial differences in physical and } \\
\text { mental health: Socio-economic status, } \\
\text { stress and discrimination. J Health } \\
\text { Psychol 1997;2(3):335-51. Doi: } \\
\text { https://doi.org/10. } \\
\text { 1177/135910539700200305. }\end{array}$ \\
\hline $\begin{array}{l}\text { Major Experiences } \\
\text { of Discrimination } \\
\text { Scale }\end{array}$ & 9 & $\begin{array}{l}\text { Assessment of discrimination, } \\
\text { such as being fired, denied } \\
\text { a job, denied housing, and } \\
\text { other related experiences. }\end{array}$ & $\begin{array}{l}\text { Williams DR, Gonzalez HM, Williams S, } \\
\text { Mohammed SA, Moomal H, Stein DJ. } \\
\text { Perceived discrimination, race and } \\
\text { health in South Africa. Soc Sci Med } \\
\text { 2008;67(3):441-52. Doi: https://doi. } \\
\text { org/10.1016/j.socscimed.2008.03. } \\
\text { 021. }\end{array}$ \\
\hline $\begin{array}{l}\text { Chronic Work } \\
\text { Discrimination } \\
\text { and Harassment: } \\
\text { Abbreviated }\end{array}$ & 12 & $\begin{array}{l}\text { Measure of the occurrence } \\
\text { and frequency of interpersonal } \\
\text { discrimination experienced } \\
\text { at work. }\end{array}$ & $\begin{array}{l}\text { Lawrence B, Suh SA. Surveying Racial } \\
\text { Discrimination: Analyses From a } \\
\text { Multiethnic Labor Market. In: Bobo LD, } \\
\text { Oliver ML, Johnson JH, Valenzuela A, } \\
\text { editors. Prismatic Metropolis: } \\
\text { Inequality in Los Angeles. New York: } \\
\text { Russell Sage Foundation; } 2000 .\end{array}$ \\
\hline $\begin{array}{l}\text { Gender Minority } \\
\text { Stress and } \\
\text { Resilience Measure }\end{array}$ & 58 & $\begin{array}{l}\text { Assessment of } 9 \text { constructs related } \\
\text { yet distinct stressors and } \\
\text { resilience factors experienced by } \\
\text { TGD } \\
\text { individuals: gender-related } \\
\text { discrimination ( } 5 \text { items), } \\
\text { gender-related rejection } \\
\text { (6 items), gender-related } \\
\text { victimization ( } 6 \text { items), } \\
\text { non-affirmation of gender } \\
\text { identity ( } 6 \text { items), internalized } \\
\text { transphobia ( } 8 \text { items), negative } \\
\text { expectations for future events } \\
\text { (9 items), concealment ( } 5 \text { items), } \\
\text { community connectedness } \\
\text { ( } 5 \text { items), and pride ( } 8 \text { items). } \\
\text { Note: Assessors can administer the } \\
\text { whole measure or choose from among } \\
\text { subscales to assess specific constructs } \\
\text { of interest. }\end{array}$ & $\begin{array}{l}\text { Testa RJ, Habarth J, Peta J, Balsam K, } \\
\text { Bockting W. Development of the Gender } \\
\text { Minority Stress and Resilience Measure. } \\
\text { Psychol Sex Orient Gend Divers } \\
\text { 2015;2(1):65-77. Doi: https://doi. } \\
\text { org/10.1037/sgd0000081. }\end{array}$ \\
\hline $\begin{array}{l}\text { Perceptions of } \\
\text { Local Stigma } \\
\text { Questionnaire } \\
\text { (Modified) }\end{array}$ & 7 & $\begin{array}{l}\text { Measure of individuals' beliefs that } \\
\text { individuals in their geographic } \\
\text { region would willing accept, hire, } \\
\text { or trust LGBT individuals. }\end{array}$ & $\begin{array}{l}\text { Herek GH, Glunt EK. Identity and } \\
\text { community among gay and bisexual } \\
\text { men in the AIDS era: Preliminary } \\
\text { findings from the Sacramento Men's } \\
\text { Health Study. In: Herek GM, Greene B, } \\
\text { editors. AIDS, Identity, and }\end{array}$ \\
\hline
\end{tabular}


Table 2. (Continued)

\begin{tabular}{|c|c|c|c|}
\hline Measure & $\begin{array}{l}\text { No. of } \\
\text { Items }\end{array}$ & Assessment content & Reference \\
\hline & & & $\begin{array}{l}\text { Community: The HIV Epidemic and } \\
\text { Lesbians and Gay Men. Newbury Park, } \\
\text { CA: Sage; } 1995 .\end{array}$ \\
\hline $\begin{array}{l}\text { Transgender } \\
\text { Adaptation } \\
\text { and Integration } \\
\text { Measure }\end{array}$ & 15 & $\begin{array}{l}\text { Assessment of stress, and distress } \\
\text { associated with transgender } \\
\text { gender identity. }\end{array}$ & $\begin{array}{l}\text { Sjoberg MD, Walch SE, Stanny CJ. } \\
\text { Development and Initial Psychometric } \\
\text { Evaluation of the Transgender } \\
\text { Adaptation and Integration Measure } \\
\text { (TG AIM). Int J Transgend } \\
\text { 2006;9(2):35-45. Doi: https://doi. } \\
\text { org/10.1300/J485v09n02_05. }\end{array}$ \\
\hline $\begin{array}{l}\text { Heterosexist } \\
\text { Harassment, } \\
\text { Rejection, and } \\
\text { Discrimination Scale }\end{array}$ & 14 & $\begin{array}{l}\text { Assessment of recent perceived } \\
\text { heterosexist harassment, } \\
\text { rejection, and discrimination. }\end{array}$ & $\begin{array}{l}\text { Szymanski DM. Does Internalized } \\
\text { Heterosexism Moderate the Link } \\
\text { Between Heterosexist Events and } \\
\text { Lesbians' Psychological Distress? Sex } \\
\text { Roles: J Res 2006;54(3-4):227-34. Doi: } \\
\text { https://doi.org/10. } \\
\text { 1007/s11199-006-9340-4. }\end{array}$ \\
\hline $\begin{array}{l}\text { Daily Heterosexist } \\
\text { Experiences } \\
\text { Questionnaire }\end{array}$ & 50 & $\begin{array}{l}\text { Comprehensive measure of various } \\
\text { minority stressors: gender } \\
\text { expression, vigilance, parenting, } \\
\text { harassment and discrimination, } \\
\text { vicarious trauma, family of origin, } \\
\text { HIV/AIDS, victimization, } \\
\text { isolation. } \\
\text { Note: Assessors can administer the } \\
\text { whole measure or choose from among } \\
\text { subscales to assess specific constructs } \\
\text { of interest. }\end{array}$ & $\begin{array}{l}\text { Balsam KF, Beadnell B, Molina Y. The Daily } \\
\text { Heterosexist Experiences } \\
\text { Questionnaire: Measuring Minority } \\
\text { Stress Among Lesbian, Gay, Bisexual, } \\
\text { and Transgender Adults. Meas Eval } \\
\text { Couns Dev 2013;46(1):3-25. Doi: } \\
\text { https://doi.org/10. } \\
\text { 1177/0748175612449743. }\end{array}$ \\
\hline $\begin{array}{l}\text { Measure of Gay } \\
\text { Related Stress }\end{array}$ & 56 & $\begin{array}{l}\text { Assessment of unique stressors } \\
\text { associated with a gay identity. }\end{array}$ & $\begin{array}{l}\text { Lewis RJ, Derlega VJ, Griffin JL, Krowinski } \\
\text { AC. Stressors for gay men and lesbians: } \\
\text { Life stress, gay-related stress, stigma } \\
\text { consciousness, and depressive } \\
\text { symptoms. J Soc Clin Psychol } \\
\text { 2003;22(6):716-29. Doi: https://doi. } \\
\text { org/10.1521/jscp.22.6.716.22932. }\end{array}$ \\
\hline $\begin{array}{l}\text { Internalized } \\
\text { Homophobia } \\
\text { Scale }\end{array}$ & 9 & $\begin{array}{l}\text { Measure of distress experienced by } \\
\text { gay and bisexual men in relation } \\
\text { to their sexual identities over the } \\
\text { past year. }\end{array}$ & $\begin{array}{l}\text { Herek GM, Gillis JR, Cogan JC. Internalized } \\
\text { stigma among sexual minority adults: } \\
\text { Insights from a psychological } \\
\text { perspective. J Couns Psychol } \\
\text { 2009;6(1):32-43. Doi: https://doi. } \\
\text { org/10.1037/a0014672. }\end{array}$ \\
\hline $\begin{array}{l}\text { LGBT People of Color } \\
\text { Microaggressions } \\
\text { Scale }\end{array}$ & 18 & $\begin{array}{l}\text { Assessment of microaggressions } \\
\text { experienced by ethnic minority } \\
\text { LGBT adults. }\end{array}$ & $\begin{array}{l}\text { Balsam KF, Molina Y, Beadnell B, Simoni J, } \\
\text { Walters K. Measuring multiple minority } \\
\text { stress: the LGBT People of Color } \\
\text { Microaggressions Scale. Cultur Divers } \\
\text { Ethnic Minor Psychol }\end{array}$ \\
\hline
\end{tabular}


Table 2. (Continued)

\begin{tabular}{|c|c|c|c|}
\hline Measure & $\begin{array}{l}\text { No. of } \\
\text { Items }\end{array}$ & Assessment content & Reference \\
\hline & & & $\begin{array}{l}\text { 2011;17(2):163-74. Doi: https://doi. } \\
\text { org/10.1037/a0023244. }\end{array}$ \\
\hline $\begin{array}{l}\text { Conflict in } \\
\text { Allegiances }\end{array}$ & 6 & $\begin{array}{l}\text { Measure of perceived conflict related } \\
\text { to } L G B \text { persons of color multiple } \\
\text { stigmatized identities. }\end{array}$ & $\begin{array}{l}\text { Sarno EL, Mohr JJ, Jackson SD, Fassinger } \\
\text { RE. When identities collide: Conflicts in } \\
\text { allegiances among LGB people of color. } \\
\text { Cultur Divers Ethnic Minor Psychol } \\
\text { 2015;21(4):550-9. Doi: https://doi. } \\
\text { org/10.1037/cdp0000026. }\end{array}$ \\
\hline $\begin{array}{l}\text { Homonegative } \\
\text { Microaggressions } \\
\text { Scale }\end{array}$ & 45 & $\begin{array}{l}\text { Assessment of perceived } \\
\text { homonegative microaggressions }\end{array}$ & $\begin{array}{l}\text { Wright AJ, Wegner RT. Homonegative } \\
\text { microaggressions and their impact on } \\
\text { LGB individuals: A measure validity } \\
\text { study. J LGBT Issues Couns } \\
\text { 2012;6(1):34-54. Doi: https://doi. } \\
\text { org/10.1080/15538605.2012.648578. }\end{array}$ \\
\hline $\begin{array}{l}\text { Sexual Orientation } \\
\text { Concealment } \\
\text { Scale }\end{array}$ & 45 & $\begin{array}{l}\text { Assessment of outness in multiple } \\
\text { social domains. }\end{array}$ & $\begin{array}{l}\text { Meyer IH, Rossano L, Ellis JM, Bradford J. } \\
\text { A brief telephone interview to identify } \\
\text { lesbian and bisexual women in random } \\
\text { digit dialing sampling. J Sex Res } \\
\text { 2002;39(2):139-144. Doi: https://doi. } \\
\text { org/10.1080/00224490209552133. }\end{array}$ \\
\hline Outness Inventory & 10 & $\begin{array}{l}\text { Brief assessment of outness to } \\
\text { important members of the } \\
\text { individuals' life, such as parents, } \\
\text { friends, close family. }\end{array}$ & $\begin{array}{l}\text { Mohr J, Fassinger R. Measuring } \\
\text { dimensions of lesbian and gay male } \\
\text { experience. Meas Eval Couns Dev } \\
\text { 2000;33:66-90. Doi: https://doi. } \\
\text { org/10.1037/t07099-000. }\end{array}$ \\
\hline
\end{tabular}

\section{The intersection of minority stress and PTSD}

In addition to higher rates of trauma exposure and PTSD, LGBTQ individuals may experience added stress as a function of the social attitudes, stigma, and prevailing policies that include lack of protections against discrimination at work, housing, and in public spaces [22]. These stressors can include systemic and institutional oppression, discrimination, and microaggression experiences that serve as persistent reminders of LGBTQ individuals' minority status [20, 23]. These external and felt social stressors, or "distal stressors," can condition LGBTQ individuals to anticipate rejection from others, experience shame, and to conceal their minority identity to prevent emotional pain, physical harm, or further trauma(s) [20, 24]. These learned adaptations, in turn, are associated with higher rates of mental and physical health complications generally [25] and can give rise to symptoms similar 
to each of the four main PTSD symptom clusters: intrusions, avoidance, negative alterations in cognition and mood, and hyperarousal. That is, intrusions share overlap with the occurrence of intrusive thoughts and rumination observed among LGBTQ individuals who experience minority stress [25], and avoidance is consistent with their elevated rates of identity concealment and social withdrawal [24]. Disruptions in cognition and mood overlap with symptoms of depression, anxiety [26], and negative thoughts of self and others observed as well [27•]. Hyperarousal, and hypervigilance in particular, has been observed following and in anticipation of discrimination [28]. Thus, the context of pervasive anti-LGBTQ sentiment can exacerbate and/or complicate recovery from trauma and can even mimic PTSD symptoms in the absence of a criterion A event.

A diagnosis of PTSD requires exposure to one or more criterion A trauma, as well as endorsement of (1) persistent intrusive re-experiencing of the event ( 1 or more symptoms), (2) avoidance of stimuli associated with the event (1 or more), (3) negative alterations in their cognitions and mood ( 2 or more), and (4) increased arousal or reactivity ( 2 or more; $[6]$ ). To be clear, we are not suggesting that minority stress leads to PTSD in the absence of criterion A trauma. However, clinicians should note that many LGBTQ individuals report exposure to criterion A trauma and that minority stress can also lead to related symptom sequela. Currently, these associations are poorly understood and warrant further research and clinical attention to better understand and more effectively intervene to address the intersecting consequences of traumatic stress and minority stress.

In the meantime, as clinicians approach PTSD treatment among LGBTQ individuals, we believe it is essential to understand the psycho-social history within their respective social, environmental, political contexts. Understanding the personal history of LGBTQ patients in context—often mired in stigma and discrimination-can aid in accurate case conceptualization, intervention planning, and treatment. As with any patient, a comprehensive, patient-centered, and culturally informed conceptualization will guide PTSD treatment planning among LGBTQ patients. It is salient to gather information not only about patients' previous experiences and associated symptoms, but about the potential functions of LGBTQ individuals' cognitive, affective, physiological, and behavioral responses to past trauma and minority stress experiences.

In a recent study of trauma-exposed LGBTQ veterans, researchers conducted semi-structured interviews and found that experiences shared by these individuals fell into four unique yet overlapping categories. Experience categories derived from these interviews included (1) "criterion A trauma," (2) "discrimination," (3) "microaggressions," and (4) "minority stress" [29••]. Importantly, while each participant had experienced criterion A trauma, several described non-criterion A events as "traumatic" (e.g., the "trauma of the closet"). Qualitative analyses also revealed significant overlap across these categories, such as criterion A trauma perpetrated on the basis of one's LGBTQ identity, which also fell under "discrimination," as well as adaptations to high impact yet noncriterion A experiences worthy of clinical attention including paranoia, hypervigilance, drug use, sexual risk taking, and heightened anxiety and depression.

These LGBTQ veterans' reports suggest that non-diagnostic characteristics (i.e., socio-cultural reactions to LGBTQ identity and expression, individual adaptions to hostile, invalidating, and/or traumatic reactions to LGBTQ identity and expression, the functions of these adaptations in the context of anti-LGBTQ environments) are important to assess. These reactions to environmental stressors can 
influence diagnostic symptom presentations and also reactions to acceptable and efficacious PTSD treatment for LGBTQ individuals [30]. We therefore recommend approaching treatment in a manner that takes into account and respects LGBTQ individuals' previous experiences, as well as past and present context. As such, the context of care delivery deserves some thought, with providers offering an environment that clearly signals support for the LGBTQ community. By directly confronting expectations of discrimination and addressing how minority stress and discrimination have impacted the patient's life, it becomes easier to determine the degree to which adaptations observed in treatment represent intervention targets and which are adaptive strategies to cope with minority stress.

\section{Practical recommendations for working with LGBTQ patients}

Among trauma-exposed LGBTQ patients, quality patient-centered communication may be particularly crucial for optimal PTSD treatment outcomes [31] given that LGBTQ individuals are more likely than the general population to experience discrimination both in daily life and while seeking mental and physical healthcare [32]. LGBTQ individuals may experience a reasonable distrust of the mental health profession due not only to personal experiences of discrimination in the context of help-seeking, but also due to the profession's longstanding history of labeling diversity in sexual orientation and gender identity as mental health disorders. This cultural and historical context is a critical barrier to LGBTQ individuals accessing mental health services and disclosing their sexual orientation and gender identity to providers. As such, effective treatment of trauma-exposed LGBTQ patients must acknowledge and counter these oppressive contexts $[2,3]$. The creation of strong patient-provider relationships through patient-centered care practices is a first essential step towards this goal. Indeed, evidence suggests that high-quality clinician communication might buffer against disclosure apprehension in the context of previous discrimination in health care settings [33].

Moreover, clinicians who are not familiar with trauma-focused or minority stress-focused treatment can still work to empower patients to be active in managing their mental and physical health [34]. For example, clinicians working with trauma-exposed LGBTQ patients might expand their traditional conceptualization of their role within a particular specialty or subfield to function as advocates for their patients, facilitating referrals, collaborating and consulting with interdisciplinary treatment teams, and acting within one's scope of competence to support patients' treatment adherence.

This work requires open dialogue about patients' LGBTQ identity and identity-related concerns. As such, clinicians are encouraged to ask patients about their sexual orientation, gender identity, and related concerns as part of the intake process, and on an ongoing basis throughout care [35]. If done effectively, such practices can impact patients' self-efficacy and autonomy, which can lead to improved emotional well-being, more effective coping, and improved functioning $[36,37]$. At the very least, patient-centered care that is affirming of LGBTQ identities can provide positive and potentially corrective treatment experience, which itself may encourage treatment adherence and promote recovery. 


\section{Evidence-based assessment}

A thoughtful approach to assessment and careful and accurate case conceptualization can aid in the provision of evidence-based care in the absence of established PTSD treatment guidelines for LGBTQ individuals. For LGBTQ patients, this includes assessment of the complex and often overlapping experiences of past trauma(s), using established clinician-administered tools, such as the Clinician-Administered PTSD Scale for DSM-5 [38], or self-report measures like the PTSD Symptom Checklist-5 [39] (see Table 1 for suggestions). In addition, assessment of non-criterion A yet highly impactful experiences such as previous and ongoing discrimination, microaggressions, and minority stressors is essential to accurate case conceptualization and effective PTSD treatment. In addition, these non-criterion A stressors may themselves be targets of intervention, such as when patients are seeking additional coping skills. To aid in this endeavor, we provide recommendations for specific screening and assessment tools to facilitate treatment planning in Tables 1 and 2.

\section{Current evidence-based treatments for PTSD}

Cognitive behavioral "trauma-focused" therapies, such as prolonged exposure therapy (PE [40]) and cognitive processing therapy (CPT [41••]), have solid empirical support for use in the general population. These treatments are effective in addressing the psychological and physiological effects of trauma and represent front-line interventions in the treatment of PTSD according to American Psychological Association (APA) Clinical Practice Guidelines [42 ••] and the National Center for PTSD [43]. From a medication perspective, selective serotonin reuptake inhibitors (SSRIs) and serotonin-norepinephrine reuptake inhibitors (SNRIs) have demonstrated some benefit in treating PTSD, though only sertraline (e.g., Zoloft) and paroxetine (e.g., Paxil) are FDA approved for the treatment of PTSD [44]. Unfortunately, little is known regarding the efficacy of either trauma-focused therapies or medication treatments in the context of

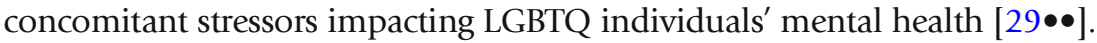

To date, no empirical study has directly tested whether the efficacy of first-line PTSD treatments is moderated by sexual and/or gender minority identity, as no randomized controlled trials of PTSD treatment report the sexual or gender minority status of their sample, nor stratify results by sexual or gender minority status $[45 \bullet \bullet, 46 \bullet \bullet]$. Moreover, it is unknown if exposure to anti-LGBTQ criterion A traumatic events, and/or comorbid experiences of minority stress impact treatment efficacy. These methodological practices limit the ability to draw empirically grounded conclusions about whether LGBTQ individuals experience comparable benefit to their non-LGBTQ counterparts from front-line PTSD treatment. In the absence of empirical guidance or established clinical guidelines, we provide preliminary treatment recommendations based on anecdotal evidence with the goal of promoting a broader discourse about the mechanisms, techniques, and assumptions that underlie, and can best advance, the treatment of PTSD among LGBTQ patients. The primary focus of this discussion is on talk therapies rather than on medications, as the former has stronger 
empirical support currently. The latter also offers interpersonal context in which the nuanced issues raised here can be systematically and therapeutically addressed. However, the importance of understanding the interplay between traumatic events, discrimination, minority stress, and microaggressions is essential for all treating providers, including those offering medication only.

To begin the review of current best-practice interventions for PTSD, it is important to note that gold-standard PTSD treatments, such as PE and CPT, were not developed for non-criterion A trauma, and that debate continues regarding the appropriateness or sufficiency of these treatments in addressing the range of clinically significant experiences faced by many LGBTQ individuals (e.g., discrimination [29••]). Specifically, PE and CPT were each derived from theoretical frameworks that assume that the lasting harms of trauma exposure are attributable to fear-based life-threat experiences and their impact on subsequent socio-cognitive and or emotional processing [47]. However, there is growing consensus that clinical distress among trauma-exposed LGBTQ individuals may stem from more than life-threat experiences. The pervasive invalidation of a patient's identity in our culture and in our health care systems, such as the pathologizing LGBTQ identities, can erode well-being due to the disruption of allostasis and ongoing allostatic load on the individual's system [48].

For example, as previously mentioned, LGBTQ individuals may also experience criterion A events that are directly related to sexual or gender minority identity (e.g., hate crimes). These experiences may threaten identity and integrity resulting in grief and shame responses that may be considerably more complex and toxic than a purely fear-based response to a non-identity linked life-threat trauma (e.g., tornado). For instance, Fredriksen-Goldsen and colleagues found that identity processes impacted by experiences of victimization, such as identity appraisal and identity management, moderated the relationship between marginalization and health outcomes in a sample of older LGBTQ adults [49]. Thus, the experience of trauma related to LGBTQ identity may uniquely impact how LGBTQ individuals manage identity disclosure and concealment, which in turn may shape access to social resources, mental health outcomes, and health promoting behaviors relevant to PTSD onset and course [50]. Unfortunately, trauma-focused therapies for PTSD, which focus predominantly on de-conditioning overgeneralized fear responses to environmental stimuli and remediation of cognitive distortions stemming from past trauma(s), were not developed to target such identity-related adaptations to trauma exposure.

Moreover, existing theories do not account for contexts in which chronic victimization experiences, elusive safety, or daily identity-based threats may influence or account for coping strategies (e.g., adaptive vigilance), negative appraisals, and emotions implicated in PTSD etiology [51, 52]). Counter to the typical approach of identifying overgeneralized beliefs, distorted thoughts, and exaggerated physiological responses to target in therapy, for many traumaexposed LGBTQ individuals, these adaptations may not be exaggerated nor distorted and may serve important ongoing safety functions, such as avoiding realistic threat of future LGBTQ-based discrimination. It might be easy for a provider to mischaracterize such an accurate appraisal of realistic environmental threats as "hypervigilance" and overlook the fact legitimate threat persists and precaution may be necessary for their patient $[29 \bullet \bullet, 50]$. Consequently, we 
would argue that to be clinically valid, any theory that operationalizes change agents in the treatment of PTSD among LGBTQ individuals must account for how the intervention targets these disparate phenomenologies. In addition, and in the absence of existing recommendations for organizing trauma-focused therapy for LGBTQ individuals, we recommend careful assessment and delivery of care in a manner that is affirming of patients' LGBTQ identity and that leverages an individualized case conceptualization to address co-occurring trauma, minority stress, and related PTSD sequela.

For example, the application of emotion processing theory [53, 54], the theoretical basis of $\mathrm{PE}$, can be extended to reduce both fear and shame associated with anti-LGBTQ criterion A trauma. Specifically, PE can be used to counteract avoidance by activating and exploring the context of memory networks linked to shame, fear, and associated cognitions (e.g., "I was assaulted for being gay. Therefore, I will be judged and rejected if I am honest and open about who I am"). Exposure-based procedures can be used to reduce problematic emotions and beliefs that maintain avoidance and limit access to social support by providing access to events that prompt these problematic emotions while simultaneously blocking ineffective emotion-expression and action (e.g., hiding, concealment of gay identity). To facilitate new learning and effectively reduce distress, it is essential that exposures occur in contexts in which the feared or avoided outcome is unlikely to occur. The therapeutic relationship is an opportunity to offer a context where that new learning can occur in relative safety, if handled appropriately by the provider. Given a broader social context in which negative interactions are pervasive for LGBTQ individuals, clinicians must be creative and flexible about structuring exposure opportunities that promote competence and mastery outside of therapy as well. These exposures can be a part of formal PE therapy or an adjunct to medication treatments when indicated. To this end, clinicians are encouraged to develop a familiarity with LGBTQ resources, community organizations, and/or support groups in their local area. The use of imaginal-exposure in addition to in vivo exposure procedures may also be helpful and provide patients an opportunity to develop skills for tolerating difficult emotions and coping with feared outcomes in a safe and affirming environment.

Similarly, tactical modifications may be applied to the use of Socratic questioning in CPT to address appraisals about threats to safety, esteem, and social acceptance among LGBTQ individuals exposed to ongoing discrimination, microaggressions, and other minority stressors. A case description of application of CPT following an anti-gay physical assault demonstrates the use of CPT to address PTSD symptoms in addition to internalized homophobia [55]. CPT entails alleviating problematic trauma-linked emotions by modifying the distorted cognitions, or stuck points that manufacture or exacerbate difficult emotions. In cases in which patient's evaluations of risk are indeed distorted, cognitive restructuring may be highly effective in alleviating suffering. However, in many cases, distressing appraisals of ongoing threats to safety, acceptance, and identity may well be reasonable and appropriate. In these cases, a shift from challenging patient's accurate appraisals of risk toward supporting the patient to identify a more affirming context is warranted. In addition, bolstering the patient's perceived ability to cope with and recover from the effects of social rejection or invalidation 
may be effective. In some cases, teaching or enhancing coping skills may be a direct focus of treatment.

\section{Treatments to address LGBTQ-related stressors}

Recent efforts to develop and evaluate treatments tailored to the concerns of LGBTQ patients have produced encouraging results. Effective Skills to Empower Effective Men (ESTEEM) is a transdiagnostic treatment developed to target minority stress and associated negative health consequences. ESTEEM is a 10session treatment that enhances emotion regulation skills, reduces avoidance patterns, and improves motivation and self-efficacy for behavior change. In the initial waitlist-controlled pilot trial of ESTEEM treatment among 63 gay and bisexual men, results demonstrated improved depression, alcohol use, and sexual risk-taking outcomes for those undergoing the treatment [56]. Although this was a small-scale pilot study, ESTEEM is currently being investigated in a large multi-site trial (ClinicalTrials.gov Identifier: NCT02929069) that can potentially lead to further evidence of effectiveness and/or insight for future intervention development.

Examination of the modular content of the ESTEEM treatment provides insight into ways it might be adapted for use among trauma-exposed LGBTQ individuals. The essential components of the ESTEEM intervention include (1) normalizing the negative impacts of minority stress; (2) promoting emotional awareness and self-regulation; (3) empowerment and assertive communication skill development; (4) cognitive restructuring around minority stress; (5) identification and validation of individuals' strengths; (5) building healthy social supports; (6) supporting adaptive and rewarding sexual expression; and (7) decreasing avoidance of emotions, situations, or people (e.g., identity concealment, social isolation [56]). The Emotion Avoidance module of the ESTEEM intervention specifically targets emotion avoidance behavior leading to unhealthy behaviors such as social isolation and substance use. Other modules with direct relevance to recovery from trauma and PTSD include those examining the impacts and developing skills to manage minority stress, empowermentbased assertiveness training and social support seeking, cognitive restructuring of maladaptive thinking patterns, and "relapse prevention" to help sustain therapeutic gains.

In addition to the ESTEEM protocol, Parsons and colleagues recently reported pilot outcomes of their intervention [57•], adapted from the Unified Protocol for Transdiagnostic Treatment of Emotional Disorders [58] and focused on promoting emotion regulation. Results provided preliminary support for the efficacy of an emotion-focused intervention to reduce anxiety and depression among gay and bisexual men [57•].

As the field stands, most attempts to develop targeted interventions for this population have focused on gay and bisexual men, and specifically on sexual risk-taking and related symptoms of anxiety, depression, and substance use which are associated with HIV transmission. For example, a trial of 43 men who have sex with men (MSM) with risky sexual behaviors and childhood sexual abuse histories were offered cognitive-behavioral therapy for trauma and self-care (CBT-TSC). The CBT-TSC treatment included a 


\section{Conclusions}

modified version of CPT treatment coupled with sexual risk reduction education and were compared to those receiving only HIV risk reduction and testing. Both PTSD symptoms and HIV risk-taking reduced over the course of CBT-TSC treatment relative to those in the control condition, with gains maintained through 9-month follow-up [21•]. However, it should be noted that the primary outcome of the CBT-TSC was risky sexual behavior and a PTSD diagnosis was not an inclusion criterion.

The development of ESTEEM and CBT-TSC and their promising outcome data provide encouraging directions for further treatment development, as well as implications for integration of its modular content with existing evidence-based PTSD treatments. That is, front-line evidencebased PTSD treatments, like PE and CPT, focus on cognitive restructuring, habituation to overgeneralized fear responses to trauma cues, and helping individuals reducing ineffective avoidance behaviors impacting recovery and quality of life. Acknowledging the important differences between intervention like ESTEEM or CBT-TSC and evidence-based PTSD treatments, we also see areas of important overlap and more importantly, opportunity for integration. In the absence of evidence-based PTSD treatments that are inclusive of minority stressors, and LGBTQbased or minority stress-oriented treatments that extend to criterion A trauma and PTSD sequela, informal integration of these interventions might help bridge the gap while researcher work to develop and evaluate novel intervention strategies. In the future, we hope these innovations will also be inclusive of lesbian and bisexual women as well as transgender individuals.

Given the pervasive nature of stress, stigma, and discrimination against LGBTQ people, and the concomitant high rates of trauma exposure, it is critical for health care providers to ensure cultural awareness, sensitivity, and responsiveness to the experiences and healthcare needs of this patient population. In this paper, we provided an overview of the key issues with respect to trauma, PTSD, minority stress, and evidence-based treatment for LGBTQ patients with which any health care provider should be aware. We also offered suggestion for screening, assessment, and evidenced-based trauma and minority stress treatment to guide clinicians in the absence of established guidelines. In so doing, we hope to impress the point about the importance of ongoing research and development in this area, which is critical to providing culturally appropriate patient-centered PTSD treatment for LGBTQ patients.

\section{Compliance with ethical standards}

\section{Conflict of interest}

Nicholas A. Livingston, Danielle Berke, James Scholl, Mollie Ruben, and Jillian C. Shipherd declare no conflict of interest. 


\section{References and Recommended Reading}

Papers of particular interest, published recently, have been

highlighted as:

- Of importance

- Of major importance

1. Kilpatrick DG, Resnick HS, Milanak ME, Miller MW, Keyes KM, Friedman MJ. National estimates of exposure to traumatic events and PTSD prevalence using DSM-IV and DSM-5 criteria. J Trauma Stress. 2013;26(5):537-47. https://doi.org/10.1002/jts.21848.

2. American Psychiatric Association. Diagnostic and statistical manual of mental disorders, (5th ed.). Washington; 2013.

3. Kessler RC, Chiu WT, Demler O, Merikangas KR, Walters EE. Prevalence, severity, and comorbidity of 12-month DSM-IV disorders in the National Comorbidity Survey Replication. Arch Gen Psychiatry. 2005;62(7):709. https://doi.org/10.1001/archpsyc.62.6.617.

4. Beckman K, Shipherd J, Simpson T, Lehavot K. Military sexual assault in transgender veterans: results from a nationwide survey. J Trauma Stress. 2018;31(2):18190. https://doi.org/10.1002/jts.22280.

Additionalcultural context of added disparity.

5. Henry RS, Perrin PB, Coston BM, Calton JM. Intimate partner violence and mental health among transgender/gender nonconforming adults. J Interpers Violence 2018:1-26. Doi: https://doi.org/10.1177/ 0886260518775148 .

6. Seelman KL, Woodford MR, Nicolazzo Z. Victimization and microaggressions targeting LGBTQ college students: gender identity as a moderator of psychological distress. J Ethn Cult Divers Soc Work. 2017;26(12):112-25. https://doi.org/10.1080/15313204.2016. 1263816 .

7. Fernández-Rouco N, Fernández-Fuertes AA, Carcedo RJ, Lázaro-Visa S, Gómez-Pérez E. Sexual violence history and welfare in transgender people. J Interpers Violence. 2017;32(19):2885-907. https://doi.org/10. $1177 / 0886260516657911$.

8. D'Augelli A, Grossman AH, Starks MT. Childhood gender atypicality, victimization, and PTSD among lesbian, gay, and bisexual youth. J Interpers Violence. 2006;21(11):1462-82. https://doi.org/10.1177/ 0886260506293482 .

9. Gilman SE, Cochran SD, Mays VM, Hughes M, Ostrow D, Kessler RC. Risk of psychiatric disorders among individuals reporting same-sex sexual partners in the National Comorbidity Survey. Am J Public Health. 2001;91(6):933-9. https://doi.org/10.2105/ajph.91.6. 933.

10. Roberts AL, Austin SB, Corliss HL, Vandermorris AK, Koenen KC. Pervasive trauma exposure among US sexual orientation minority adults and risk of posttraumatic stress disorder. Am J Public Health. 2010;100(12):2433-41. https://doi.org/10.2105/ AJPH.2009.168971.

11. Roberts AL, Rosario M, Corliss HL, Koenen KC, Austin $\mathrm{SB}$. Childhood gender nonconformity: a risk indicator for childhood abuse and posttraumatic stress in youth. Pediatrics. 2012;129(3):410-7. https://doi.org/10. 1542/peds.2011-1804.

12. Shipherd JC, Maguen S, Skidmore WC, Abramovitz SM. Potentially traumatic events in a transgender sample: frequency and associated symptoms. Traumatology. 2011;17(2):56-67. https://doi.org/10.1177/ 1534765610395614.

13. Valera RJ, Sawyer RG, Schiraldi GR. Perceived health needs of inner-city street prostitutes: a preliminary study. Am J Health Behav. 2001;25(1):50-9. https:// doi.org/10.5993/ajhb.25.1.6.

14. Whitbeck LB, Chen X, Hoyt DR, Tyler KA, Johnson KD. Mental disorder, subsistence strategies, and victimization among gay, lesbian, and bisexual homeless and runaway adolescents. J Sex Res. 2004;41(4):329-42. https://doi.org/10.1080/00224490409552240.

15. Fortin AH, Dwamena FC, Frankel RM. Smith's patientcentered interviewing: an evidence-based method. New York: McGraw-Hill Medical; 2012.

16. Martell CR, Williams ME. The social context of clinical practice with sexual minority clients: commentary on the special issue. Cogn Behav Pract. 2019;26(2):300-6. https://doi.org/10.1016/j.cbpra.2018.12.001.

17.• Puckett J. An ecological approach to therapy with gender minorities. Cogn Behav Pract. 2019;26(4):647-55. https://doi.org/10.1016/j.cbpra.2019.08.002

Important review and commentary on addressing the healthcare needs of transgender and gender diverse (TGD) patients across micro, mezzo, and macro-level spheres, corresponding to the individual, local/community, and state or national policy levels, respectively.

18. Shipherd JC. Defining competence when working with sexual and gender minority populations: training models for professional development. Clin Psychol. 2015;22(2):101-4. https://doi.org/10.1111/cpsp. 12100.

19. Ong LM, de Haes JC, Hoos AM, Lammes FB. Doctorpatient communication: a review of the literature. Soc Sci Med. 1995;40(7):903-18. https://doi.org/10.1016/ 0277-9536(94)00155-m.

20. Meyer IH. Prejudice, social stress, and mental health in lesbian, gay, and bisexual populations: conceptual 
issues and research evidence. Psychol Bull. 2003;129(5):674-97. https://doi.org/10.1037/00332909.129.5.674.

21. O'Cleirigh C, Safren SA, Taylor SW, Goshe BM, Bedoya CA, Marquez SM, et al. Cognitive behavioral therapy for trauma and self-care (CBT-TSC) in men who have sex with men with a history of childhood sexual abuse: a randomized controlled trial. AIDS Behav. 2019;23(9):2421-31. https://doi.org/10.1007/ s10461-019-02482-z

First trauma-focused intervention designed for men who have sex with me.

22. Riggs DW, Treharne GJ. Decompensation: a novel approach to accounting for stress arising from the effects of ideology and social norms. J Homosex. 2017;64(5):592-605. https://doi.org/10.1080/ 00918369.2016 .1194116$.

23. Livingston NA, Flentje A, Heck NC, Szalda-Petree A, Cochran BN. Ecological momentary assessment of daily discrimination experiences and nicotine, alcohol, and drug use among sexual and gender minority individuals. J Consult Clin Psychol. 2017;85(12):1131-43. https://doi.org/10.1037/ccp0000252.

24. Pachankis JE. The psychological implications of concealing a stigma: a cognitive-affective-behavioral model. Psychol Bull. 2007;133(2):328-45. https://doi.org/ 10.1037/0033-2909.133.2.328.

25. Hatzenbuehler ML. How does sexual minority stigma "get under the skin"? A psychological mediation framework. Psychol Bull. 2009;135(5):707-30. https://doi.org/10.1037/a0016441.

26. Eldahan AI, Pachankis JE, Jonathon Rendina H, Ventuneac A, Grov C, Parsons JT. Daily minority stress and affect among gay and bisexual men: a 30-day diary study. J Affect Disord. 2016;190:828-35. https://doi. org/10.1016/j.jad.2015.10.066.

27. Dworkin ER, Gilmore AK, Bedard-Gilligan M, Lehavot K, Guttmannova K, Kaysen D. Predicting PTSD severity from experiences of trauma and heterosexism in lesbian and bisexual women: a longitudinal study of cognitive mediators. J Couns Psychol. 2018;65(3):32433. https://doi.org/10.1037/cou0000287

Longitudinal study of the effects of trauma and minority stressors (e.g., discrimination) on proximal stressors (e.g., shame, internalized heterosexism) and PTSD symptoms among sexual minority individuals.

28. Rood BA, Reisner SL, Surace FI, Puckett JA, Maroney MR, Pantalone DW. Expecting rejection: understanding the minority stress experiences of transgender and gender-nonconforming individuals. Transgend Health. 2016;1(1):151-64. https://doi.org/10.1089/trgh. 2016.0012.

29.• Livingston NA, Berke DS, Ruben MA, Matza AR, Shipherd JC. Experiences of trauma, discrimination, microaggressions, and minority stress among traumaexposed LGBT veterans: unexpected findings and unresolved service gaps. Psychol Trauma.

2019;11(7):695-703. https://doi.org/10.1037/ tra0000464
Qualitative account of LGBTQ veterans' intersecting and overlapping experiences of trauma, discrimination, microaggressions, and related PTSD and other mental health symptom sequelae. The results of this study highlight the complex, overlapping, and intersectional nature of trauma and minority stress, as well as important cultural factors and treatment implications relevant to the care of LGBTQ veterans.

30. Berke DS, Maples-Keller JL, Richards P. LGBTQ perceptions of psychotherapy: a consensual qualitative analysis. Prof Psychol Res Pract. 2016;47(6):373-82. https://doi.org/10.1037/pro0000099.

31. Ruben MA, Fullerton M. Proportion of patients who disclose their sexual orientation to healthcare providers and its relationship to patient outcomes: a metaanalysis and review. Patient Educ Couns. 2018;101(9):1549-60. https://doi.org/10.1016/j.pec. 2018.05.001.

32. Bolderston A, Ralph S. Improving the health care experiences of lesbian, gay, bisexual and transgender patients. Radiography. 2016;22(3):e207-11. https:// doi.org/10.1016/j.radi.2016.04.011.

33. Ruben MA, Livingston NA, Berke DS, Matza AR, Shipherd JC. Lesbian, gay, bisexual, and transgender veterans' experiences of discrimination in health care and their relation to health outcomes: a pilot study examining the moderating role of provider communication. Health Equity. 2019;3(1):480-8. https://doi.org/10. 1089/heq.2019.0069.

34. Heisler M, Bouknight RR, Hayward RA, Smith DM, Kerr EA. The relative importance of physician communication, participatory decision making, and patient understanding in diabetes self-management. J Gen Intern Med. 2002;17(4):243-52. https://doi.org/10. 1046/j.1525-1497.2002.10905.x.

35. Ruben MA, Blosnich JR, Dichter ME, Luscri L, Shipherd JC. Will veterans answer sexual orientation and gender identity questions? Med Care. 2017;55(Suppl 9 Suppl 2):S85-9. https://doi.org/10.1097/MLR. 0000000000000744.

36. Shipherd J, Sloan C. The therapy room and beyond: necessary action when working with gender minority people. Cogn Behav Pract. 2019;26(4):589-91. https://doi.org/10.1016/j. cbpra.2019.07.011.

37. Sloan C, Shipherd J. An ethical imperative: effectively reducing SGM disparities utilizing a multi-level intervention approach. Cogn Behav Pract. 2019;26(2):23942. https://doi.org/10.1016/j.cbpra.2019.02.001.

38. Weathers FW, Bovin MJ, Lee DJ, Sloan DM, Schnurr PP, Kaloupek DG, et al. The Clinician-Administered PTSD Scale for DSM-5 (CAPS-5): development and initial psychometric evaluation in military veterans. Psychol Assess. 2018;30(3):383-95. https://doi.org/10.1037/ pas0000486.

39. Weathers FW, Litz BT, Keane TM, Palmieri PA, Marx BP, Schnurr PP. The PTSD Checklist for DSM-5 (PCL-5). http://www.ptsd.va.gov. Published 2013. Accessed November 4, 2019. 
40. Foa EB, Hembree EA, Rothbaum BO. Prolonged exposure therapy for PTSD. New York: Oxford University Press; 2007.

41.• Resick PA, Monson CM, Chard KM. Cognitive processing therapy for PTSD. New York: Guilford Press Publications; 2017.

Updated manual for Cognitive Processing Therapy which, along with Prolonged Exposure therapy, is a front-line traumafocused therapy recommended by the American Psychological Association.

42.• American Psychological Association. PTSD treatments. https://www.apa.org/ptsdguideline/treatments/index. aspx. Published 2017. Accessed November 4, 2019.

Practice recommendations published to highlight which PTSD treatments currently have the best scientific evidence to support their effectiveness, and recommendations for which interventions to use when working with patients with PTSD.

43. National Center for PTSD. PTSD: National Center for PTSD. http://www.ptsd.va.gov. Published 2019. Accessed November 4, 2019.

44. Kelmendi B, Adams TG, Southwick S, Abdallah CG, Krystal JH. Posttraumatic stress disorder: an integrated overview of the neurobiological rationale for pharmacology. Clin Psychol. 2017;24(3):281-97. https://doi. org/10.1111/cpsp.12202.

45. Heck NC, Mirabito LA, LeMaire K, Livingston NA, Flentje A. Omitted data in randomized controlled trials for anxiety and depression: a systematic review of the inclusion of sexual orientation and gender identity. J Consult Clin Psychol. 2017;85(1):72-6. https://doi. org/10.1037/ccp0000123.

46.• Shipherd J, Berke D, Livingston N. Trauma recovery in the transgender and gender diverse (TGD) community: extensions of the minority stress model for treatment planning. Cogn Behav Pract. 2019;26(4):629-46. https://doi.org/10.1016/j.cbpra.2019.06.001.

Clinical review article focused on the treatment of minority stress, PTSD, and related mental health concerns (e.g., substance use, depression, sleep disturbance) among TGD individuals. Discussion revolves around current practices and future recommendations for prevention and intervention strategies spanning micro (e.g., individual therapy), mezzo (e.g., creating inclusive clinics), and macro spheres (e.g., improving legal protections for TGD individuals).

47. Steenkamp MM, Nash WP, Lebowitz L, Litz BT. How best to treat deployment-related guilt and shame: commentary on Smith, Duax, and Rauch. Cogn Behav Pract. 2013;20(4):471-5. https://doi.org/10.1016/j. cbpra.2013.05.002.

48. McEwen B. Allostasis and allostatic load: implications for neuropsychopharmacology. Neuropsychopharmacol. 2000;22:108-24. https://doi.org/10.1016/S0893133X(99)00129-3.

49. Fredriksen-Goldsen KI, Kim H-J, Bryan AEB, Shiu C, Emlet CA. The cascading effects of marginalization and pathways of resilience in attaining good health among LGBT older adults. Gerontologist. 2017;57(Suppl 1):S72-83. https://doi.org/10.1093/geront/gnw170.
50. Livingston NA, Flentje A, Brennan J, Mereish E, Reed O, Cochran B. Real-time associations between discrimination and anxious and depressed mood among sexual and gender minorities: the moderating effects of lifetime victimization and identity concealment. Psychol Sex Orientat Gend Divers In press.

51. Stein JY, Wilmot DV, Solomon Z. Does one size fit all? Nosological, clinical, and scientific implications of variations in PTSD criterion A. J Anxiety Disord. 2016;43:106-17. https://doi.org/10.1016/j.janxdis. 2016.07.001.

52. Ngamake ST, Walch SE, Raveepatarakul J. Discrimination and sexual minority mental health: mediation and moderation effects of coping. Psychol Sex Orientat Gend Divers. 2016;3(2):213-26. https://doi.org/10. $1037 /$ sgd0000163.

53. Foa EB, Kozak MJ. Emotional processing of fear: exposure to corrective information. Psychol Bull. 1986;99(1):20-35. https://doi.org/10.1037/00332909.99.1.20.

54. Wisco BE, Baker AS, Sloan DM. Mechanisms of change in written exposure treatment of posttraumatic stress disorder. Behav Ther. 2016;47(1):66-74. https://doi. org/10.1016/j.beth.2015.09.005.

55. Kaysen D, Lostutter TW, Goines MA. Cognitive processing therapy for acute stress disorder resulting from an anti-gay assault. Cogn Behav Pract. 2005;12(3):278-89. https://doi.org/10.1016/s10777229(05)80050-1.

56. Pachankis JE, Hatzenbuehler ML, Rendina HJ, Safren SA, Parsons JT. LGB-affirmative cognitive-behavioral therapy for young adult gay and bisexual men: a randomized controlled trial of a transdiagnostic minority stress approach. J Consult Clin Psychol. 2015;83(5):875-89. https://doi.org/10.1037/ cсp0000037.

57. Parsons JT, Rendina HJ, Moody RL, Gurung S, Starks TJ, Pachankis JE. Feasibility of an emotion regulation intervention to improve mental health and reduce HIV transmission risk behaviors for HIV-positive gay and bisexual men with sexual compulsivity. AIDS Behav. 2017;21(6):1540-9. https://doi.org/10.1007/s10461016-1533-4

New cognitive-behavioral intervention designed to help gay and bisexual men manage emotions and reduce sexual risk and related risk-taking behaviors.

58. Barlow DH, Farchione TJ, Fairholme CP, Ellard KK, Boisseau CL, Allen LB, et al. Unified protocol for transdiagnostic treatment of emotional disorders: therapist guide. New York: Oxford University Press; 2011.

\section{Publisher's Note}

Springer Nature remains neutral with regard to jurisdictional claims in published maps and institutional affiliations. 